Teologia i Moralność, volumen 12(2017), numer 1(21)

doi: 10.14746/tim.2017.21.1.6

HUBERT PILARCZYK

Uniwersytet im. Adama Mickiewicza w Poznaniu

Wydział Teologiczny

ANNA WIERDZKA-PILARCZYK

Uniwersytet im. Adama Mickiewicza w Poznaniu

Wydział Teologiczny

MARTYNA PILARCZYK

Uniwersytet Mikołaja Kopernika w Toruniu

Wydział Prawa i Administracji

\title{
Migracja w kontekście duszpasterstwa rodzin wyzwaniem dla współczesnego Kościoła. Perspektywa prawna, psychologiczna i teologiczna
}

Od zarania dziejów różne grupy ludzkie przemieszczały się i migrowały, świadectwa tych wydarzeń przekazują rękopisy i starodruki ${ }^{1}$. Wydarzenia te zawsze mocno ingerują $\mathrm{w}$ wymiar etniczny zarówno pojedynczych państw, jak i całych kontynentów. Temat ten w ostatnim czasie powrócił na polityczną i naukową arenę głównie ze względu na obecną sytuację w Syrii, Iraku, państwach Bliskiego Wschodu, budząc kontrowersje związane z nazywaniem niektórych zjawisk związanych z przemieszczaniem się ludności. W związku $\mathrm{z}$ tym zagadnienie migracji jest wciąż aktualne, co więcej, w dyskursie naukowym przybiera ono wymiar interdyscyplinarny. Zwrócili na nie uwagę reprezentanci różnych dziedzin²: socjologowie, etycy, geografowie, etnografowie, kulturoznawcy, prawnicy, psychologowie czy teologowie. We właściwy

${ }^{1}$ Do najsłynniejszych zalicza się wiek IV-VI, kiedy to plemiona barbarzyńskie Germanów i Hunów udawały się do Imperium Rzymskiego.

2 Zob. A. Walaszek, Migracje Europejczyków 1650-1914, Kraków 2007; P. Wróbel, Migracje Żydów polskich. Próba syntezy, „Biuletyn Żydowskiego Instytutu Historycznego”, styczeń-czerwiec 1998, nr 1/2 (185/186), s. 3-30; Migracje: dzieje, typologia, definicje, red. A. Furdal, 
dla siebie sposób zajmują się oni badaniami i zależnościami społeczno-kulturowymi, których podmiotem jest migracja. Niniejsza publikacja jest próbą podjęcia kwestii migracyjnych z trzech perspektyw: psychologicznej, prawnej i teologicznej, a szeroko rozumiane pojęcie zjawisk migracyjnych chcemy zawęzić do migracji w kontekście rodziny jako najmniejszej komórki społecznej, której owo zjawisko dotyczy. Z takiego właśnie punktu widzenia będziemy rozpatrywali wskazane $\mathrm{w}$ temacie artykułu zagadnienia.

\section{Uchodźca a emigrant}

Motyw migracji wpisany jest $\mathrm{w}$ historyczne dzieje Polski i w znakomitej większości przypadków był on silnie związany z sytuacją polityczną zarówno w naszym kraju, jak i poza jego granicami. Wystarczy chociażby wspomnieć najliczniejszy w historii Polski ruch emigracyjny spowodowany niepowodzeniem i upadkiem powstania listopadowego. Nie trzeba przekonywać o tym, w jak opłakanej sytuacji znajdowali się wtedy Polacy - zarówno ci, którzy zmuszeni byli do wyjazdu z kraju, jak i ci, którzy w nim pozostali. W gronie emigrantów znajdowały się także jednostki wybitne reprezentujące zarówno świat polityki, jak i sztuki, m.in.: książę Adam Jerzy Czartoryski, Fryderyk Chopin, Adam Mickiewicz, Juliusz Słowacki czy Józef Bem. Warto zauważyć, że choć historycy nazywają ich emigrantami, nie ma wątpliwości, że z uwagi na ich ówczesną sytuację życiową i polityczną dziś mogliby zostać nazwani uchodźcami. Świadomość własnej historii niejednokrotnie nie ma jednak takiej siły oddziaływania na ludzkie poglądy, jak obawy i niepewność podsycane dodatkowo posępnymi wiadomościami płynącymi ze świata. Wiele osób, broniąc swojego zachowawczego stanowiska w sprawie uchodźców, będzie twierdzić, że „czasy się zmieniły”. Niektórzy zwrócą uwagę na fakt, że aktualnie Polacy przebywający za granicą również spotkają się z mniejszymi lub większymi przejawami niechęci ze strony obywateli czy władz państwa, do którego się udali. Niejednokrotnie może zostać podniesiony argument strachu przed różnicami światopoglądowymi (zwłaszcza religijnymi, politycznymi i kulturowymi), które w skrajnej wersji mogą przybrać formę zamachów i siłowego narzucania swoich poglądów. Inni, odpierając apele o pomoc, powoływać się będą na prawo narodu jako suwerena do decydowania o najważniejszych sprawach państwa. Powodów i obaw jest wiele, jednak czy są one słuszne?

W celu rozwiania przynajmniej części wątpliwości warto przywołać art. 1 ust. F Konwencji dotyczącej statusu uchodźców, sporządzonej w Gene-

W. Wysoczański, Wrocław 2006; R. Jończy, Migracje zarobkowe ludności autochtonicznej z województwa opolskiego: studium ekonomicznych determinant i konsekwencji, Opole 2003. 
wie 28 lipca 1951 roku $^{3}$ (Polska stała się stroną konwencji genewskiej dotyczącej statusu uchodźców w 1991 roku). Zgodnie ze wspomnianym artykułem

postanowienia niniejszej Konwencji nie mają zastosowania do osoby, w stosunku do której istnieją poważne podstawy, aby sądzić, że: a) dokonała zbrodni przeciwko pokojowi, zbrodni wojennej lub zbrodni przeciwko ludzkości w rozumieniu aktów międzynarodowych opracowanych dla ustanowienia przepisów odnoszących się do tych zbrodni; b) dokonała poważnej zbrodni o charakterze niepolitycznym poza państwem, które ją przyjęło, przed uznaniem jej za uchodźcę; c) jest winną czynów sprzecznych z celami i zasadami Narodów Zjednoczonych ${ }^{4}$.

Choć błędem jest uważanie słów „emigrant” i „uchodźca” za jednoznaczne, obecnie wyraźna jest tendencja do traktowania ich jako synonimy. Ta praktyka sprawia, że pojęcie „uchodźcy” niesłusznie nabiera pejoratywnego znaczenia. Miewa to również daleko idące skutki prawne. Zdarza się, że osobom, które faktycznie znajdują się w potrzebie, odmawia się pomocy, ponieważ są one oceniane z pewnym uprzedzeniem, spowodowanym doświadczeniem i obserwowaniem negatywnych zachowań ludzi, którzy choć pod pewnymi względami są do nich podobni (narodowość, system wartości, religia, funkcjonowanie w społeczeństwie) de facto znajdują się w zupełnie innej sytuacji i z uwagi na to przysługuje im odmienny status. Problem ten został zauważony przez wysokiego komisarza Organizacji Narodów Zjednoczonych ds. Uchodźców - Antónia Guterresa. Uważa on, że „od początku naszej cywilizacji wierzyliśmy, że człowiek uciekający przed wojną zasługuje, by go chronić. Dziś najbogatsi z nas to podważają, wmawiając nam, że uchodźcy to cwaniacy albo terroryści. [...] Ci, którzy mogą pomóc, zatrzaskują drzwi przed tymi, którzy szukają bezpieczeństwa. To groźne i moralnie złe"s.

Ważne jest uświadomienie sobie, że uchodźca zdecydowanie różni się od emigranta, który przybywa do obcego kraju jako cudzoziemiec ${ }^{6}$ motywowany głównie chęcią poprawienia swojej sytuacji bytowej i ekonomicznej. Różnice te uwidacznia najdosadniej definicja legalna uchodźcy ustanowiona przez Wysokie Umawiające się Strony w art. 1A Konwencji dotyczacej statusu uchodźców z 1951 roku. Z analizy tego dokumentu wynika, że - poza przypadkami enumeratywnie wyszczególnionymi - uchodźcą jest osoba, która

${ }^{3}$ Zob. Konwencja dotycząca statusu uchodźców, sporządzona w Genewie dnia 28 lipca 1951 r., Dz.U. 1991 nr 119 poz. 515.

${ }^{4}$ Tamże, art. 1 ust. F

5 M. Urzędowska, Rak naszych czasów, http://wyborcza.pl/1,75968,18423725,rak-naszychczasow.html [dostęp: 25.08.2016].

${ }^{6}$ Zob. art. 3 pkt. 2 ustawy z dnia 12 grudnia 2013 r. o cudzoziemcach, Dz.U. 2013 poz. 1650. - w rozumieniu ustawy cudzoziemcem jest każdy, kto nie posiada obywatelstwa polskiego. 
na skutek uzasadnionej obawy przed prześladowaniem z powodu swojej rasy, religii, narodowości, przynależności do określonej grupy społecznej lub z powodu przekonań politycznych przebywa poza granicami państwa, którego jest obywatelem, i nie może lub nie chce z powodu tych obaw korzystać z ochrony tego państwa, albo która nie ma żadnego obywatelstwa i znajdując się na skutek podobnych zdarzeń, poza państwem swojego dawnego stałego zamieszkania nie może lub nie chce z powodu tych obaw powrócić do tego państwa ${ }^{7}$ (Dz.U. $1991 \mathrm{nr} 119$ poz. 515).

\section{Bodźce legislacyjne}

Należy zwrócić uwagę także na pobudki, którymi kierowały się Wysokie Umawiające się Strony, ustanawiając wspomnianą konwencję, jak bowiem czytamy w jej preambule, jedną z głównych przyczyn jej powstania było „,̇yczenie, aby wszystkie państwa, uznając społeczny i humanitarny charakter problemu uchodźców, zrobiły wszystko co w ich mocy, by problem ten nie stał się przyczyną napięć między państwami"”.

Świadomość społecznego i humanitarnego podłoża problematyki związanej z uchodźcami, a także chęć uniknięcia międzypaństwowych konfliktów stała się również przyczyną wydania przez Radę (WE) Rozporządzenia nr 343/2003 z dnia 18 lutego 2003 roku, powszechnie znanego pod nazwą Rozporzadzenie Dublin $I I^{9}$. Zawiera ono przede wszystkim wytyczne, którymi powinny kierować się państwa Unii Europejskiej, rozpatrując wniosek o azyl i zapobiegając równocześnie dwóm zjawiskom: refugees on orbit i asylum shopping. Określenie refugees on orbit zrodziło się na skutek praktyki państw, które uchylały się od rozpatrywania wniosków o azyl. W związku z tym powszechne były sytuacje, w których osoby starające się o uzyskanie statusu uchodźcy przez wiele lat „orbitowały” pomiędzy różnymi państwami Unii Europejskiej, mając nadzieję, że któreś z nich w końcu zdecyduje się na rozpatrzenie ich wniosku. $Z$ kolei asylum shopping to zjawisko nadużywania procedury azylowej, które przejawiało się w praktyce składnia kolejno lub jednocześnie przez jedną osobę licznych wniosków o azyl w różnych państwach

${ }^{7}$ Zob. art. 1A Konwencji..., dz. cyt. Protokół dotyczący statusu uchodźców sporządzony w Nowym Yorku dnia 31 stycznia 1967 r. (Polska stała się jego sygnatariuszem w 1991 r.) rozszerzył zawartą w Konwencji definicję uchodźcy, likwidując przede wszystkim ograniczenia czasowe i geograficzne.

${ }^{8}$ Zob. Preambuła Konwencji..., dz. cyt.

${ }^{9}$ Zob. Rozporządzenie Rady (WE) nr 343/2003 z dnia 18 lutego 2003 r. ustanawiające kryteria i mechanizmy określania państwa członkowskiego właściwego dla rozpatrywania wniosku o azyl, wniesionego w jednym z państw członkowskich przez obywatela państwa trzeciego, Dz.U. L 50 z 25.2.2003. 
Unii Europejskiej. Działanie takie miało przede wszystkim na celu wydłużenie czasu trwania toczącej się procedury i niejednokrotnie pozwalało na oddalenie w czasie momentu wydania decyzji odmownej ${ }^{10}$.

\section{Zasada jedności rodziny}

Spośród katalogu zasad ogólnych Rozporządzenia Dublin II w kontekście poruszanego tematu najistotniejsza będzie zasada jedności rodziny. $\mathrm{Na}$ jej wagę i doniosłość wskazuje to, że zajmuje ona pierwszą pozycję na liście kryteriów stosowanych podczas rozpatrywania wniosku o azyl. Należy zaznaczyć, że kolejność poszczególnych zasad nie jest przypadkowa. Lista stanowi swego rodzaju piramidę wartości, na której szczycie znajduje się zasada jedności rodziny ${ }^{11}$.

W celu prowadzenia dalszych rozważań należy odpowiedzieć na zasadnicze pytanie o to, kogo należy uważać za członka rodziny. Upraszczając definicję zawartą w Rozporzadzeniu, o ile rodzina istniała już w kraju pochodzenia, za jej członka uważać będziemy przede wszystkim małżonka lub partnera stanu wolnego w stabilnym związku, a także nieletnie dzieci z wcześniej wspomnianych związków. Członkiem rodziny będzie także ojciec, matka lub opiekun, o ile wnioskodawca lub uchodźca jest osobą nieletnią i stanu wolnego $^{12}$. Dzięki zasadzie jedności rodziny osoby ubiegające się o azyl uzyskują szereg gwarancji. Przede wszystkim w myśl art. 6 Rozporzadzenia: „W przypadku gdy osoba ubiegająca się o azyl jest nieletnim pozbawionym opieki, Państwem Członkowskim odpowiedzialnym za rozpatrywanie wniosku jest to państwo, w którym członek jego lub jej rodziny przebywa zgodnie z prawem, pod warunkiem, że leży to w najlepszym interesie nieletniego [... $]^{\prime 13}$. Treść tego przepisu dopełnia art. 7, który reguluje przypadki, gdy osoba ubiegająca

${ }^{10}$ Por. D. Głowacka, Rozporzadzenie Dublin II, http://www.refugee.artnet.pl/?mod=knowbase \&path=2834 \&PHPSESSID=349b36996e60d85b6fedb9ef930bdf89 [dostęp: 4.10.2016].

11 Zob. Rozporządzenie Rady (WE) nr 343/2003...dz. cyt.

12 Tamże, art. 2, pkt. i: „«Członkowie rodziny» oznaczają, o ile rodzina już istaniała w kraju pochodzenia, następujących członków rodziny wnioskodawcy, którzy są obecni na terytorium Państwa Członkowskich: (1) małżonek osoby ubiegającej się o azyl lub jej albo jego partner stanu wolnego w stabilnym związku, w przypadku gdy ustawodawstwo lub praktyka danego Państwa Członkowskiego traktuje związki pozamałżeńskie $\mathrm{w}$ sposób porównywalny $\mathrm{z}$ traktowaniem związków małżeńskich na podstawie ich przepisów prawa odnoszących się do cudzoziemców; (2) nieletnie dzieci ze związku określonego w (i) lub składającego wniosek, pod warunkiem, że nie są żonate lub zamężne i znajdują się na utrzymaniu składającego wniosek oraz bez względu na to, czy zostały urodzone w czy poza związkiem małżeńskim lub adoptowane zgodnie z przepisami prawa krajowego; (3) ojciec, matka lub opiekun, jeżeli wnioskodawca lub uchodźca jest osobą nieletnią i stanu wolnego".

13 Tamże, art. 6. 
się o azyl w danym państwie członkowskim ma w tym państwie członka rodziny, który został już upoważniony do zamieszkiwania w nim na stałe jako uchodźca. Gdy zaistnieje wyżej opisana sytuacja i gdy takie jest życzenie osoby zainteresowanej, dane państwo członkowskie - w myśl zasady jedności rodziny - jest odpowiedzialne za rozpatrywanie wniosku o udzielenie azylu ${ }^{14}$.

Gdyby jednak w określonej sytuacji nie zaistniały powyższe okoliczności, a co za tym idzie, nie zostałyby spełnione przesłanki zastosowania wyżej wspomnianych przepisów Rozporządzenia Dublin II, państwa członkowskie wrażliwe na dobro rodziny mogą połączyć jej członków, powołując się na zawartą w Rozdziale IV „Klauzulę humanitarną”. Jej istota sprowadza się do tego, że nawet jeśli dane państwo członkowskie nie jest odpowiedzialne na podstawie kryteriów wymienionych w Rozporzadzeniu do rozpatrywania wniosku o udzielenie azylu, może połączyć zarówno członków rodziny, jak i innych krewnych, jeżeli uzna to za uzasadnione z przyczyn humanitarnych (brane pod uwagę są tu przede wszystkim względy rodzinne i kulturowe). Klauzula ta ma zastosowanie w szczególności, gdy osoba zainteresowana pozostaje na utrzymaniu członka rodziny lub krewnego lub jest uzależniona od jego pomocy (zwłaszcza ze względu na stan ciąży, opiekę nad niemowlęciem, ciężką chorobę lub podeszły wiek). Powyższe okoliczności stanowią dla państwa członkowskiego przesłanki zarówno nierozłączania, jak i łączenia osoby ubiegającej się o uzyskanie azylu z osobą z nią spokrewnioną ${ }^{15}$.

\section{Prawa i obowiązki uchodźców}

Lekkomyślne i krótkowzroczne byłoby przekonanie zakładające, że problemy uchodźców rozwiązują się wraz z uzyskaniem przez nich azylu. Do zapewnienia im spokojnego i godnego życia w nowym miejscu, a także ułatwienia procesu integracji niezbędny jest szereg tzw. gwarancji. Przewiduje je wspomniana już wcześniej konwencja genewska traktująca o statusie uchodźców. Wśród licznych regulacji szczególne znaczenie należy przypisać zasadzie niedyskryminacji, w myśl której „Umawiające się Państwa będą stosowały postanowienia niniejszej Konwencji do uchodźców bez względu na ich rasę, religię lub państwo pochodzenia"16. Postanowienie to jest ważne chociażby z tego względu, że niejednokrotnie to właśnie dyskryminacja, a często wręcz prześladowania, są przyczyną szukania przez te osoby schronienia poza granicami ich ojczyzny. Analiza kolejnych artykułów Konwencji ukazuje, że

\footnotetext{
14 Tamże, art. 7.

15 Tamże, art. 15.

16 Zob. art. 3 Konwencji..., dz. cyt.
} 
w wielu sytuacjach i dziedzinach życia uchodźcom przyznawane są takie same prawa i taka sama ochrona, jaka przysługuje obywatelom danego państwa. To swoiste równouprawnienie występuje m.in. w sferze wolności religijnej, praw artystycznych, dostępu do sądów, oświaty publicznej na szczeblu podstawowym czy opieki społecznej. Mówiąc o licznych uprawnieniach, należy zaznaczyć, że uchodźcy nie są osobami stojącymi ponad prawem, ponieważ „Każdy uchodźca ma - w stosunku do państwa, w którym się znajduje - obowiązki, które obejmują $\mathrm{w}$ szczególności przestrzeganie praw i przepisów, a także środków podjętych w celu utrzymania porządku publicznego"17.

\section{Psychologiczne uwarunkowania dorosłych migrantów}

Oprócz zagwarantowania pewnych zasad i przywilejów prawnych, których zadaniem jest porządkowanie kwestii i pomoc człowiekowi w funkcjonowaniu w społeczeństwie (w przypadku migrantów często jest to środowisko odmienne od tego, w którym wcześniej funkcjonował), trzeba pamiętać, że człowiek jest przede wszystkim istotą psycho-duchową. Wyjątkowość każdego człowieka powoduje zaistnienie, często złożonych i uwarunkowanych różnymi wcześniejszymi przeżyciami (wydarzeniami z dzieciństwa, wpływem środowiskowym, obecną sytuacją życiową, stanem cywilnym) reakcji i stanów emocjonalnych właściwych tylko tej konkretnej osobie. Podobnie jest w sytuacji zjawiska migracji, które pociąga za sobą istotne konsekwencje dla życia osoby i jej wspólnoty rodzinnej. W omawianym przypadku widocznym skutkiem jest restrukturyzacja rodziny oraz pojawiająca się często zamiana ról i odpowiedzialności za poszczególne zadania podejmowane w systemie rodzinnym. Szczególnym obszarem, gdzie można zaobserwować zmiany spowodowane dłuższą rozłąką między bliskim czy też opuszczeniem stałego miejsca pobytu, jest wymiar psychiczny i emocjonalny. Każde bowiem rozstanie $\mathrm{z}$ osobami bliskimi sprawia, że człowiek obciążony jest bagażem różnych emocji, od smutku, lęku, tęsknoty, poczucia osamotnienia aż po nadzieję na lepsze jutro. Mimo iż w literaturze uwypuklany jest częściej kontekst negatywny zjawiska migracji ${ }^{18}$, można dopatrywać się tu również szans na budowanie nowych kompetencji i uwypuklanie istniejących zasobów, zarówno indywidualnych, jak i grupowych. Naukowy obiektywizm domaga się spojrzenia na obszar migracji jako źródła strat i zysków dla pojedynczej osoby oraz całej rodziny. Nie umniejszając negatywnych konsekwencji rozłąki, chcemy zwrócić

17 Tamże, art. 2.

18 Por. M. Dzięgielewski, Społeczne i kulturowe skutki migracji poakcesyjnej na łamach tygodników opinii w latach 2004-2012, „Studia Migracyjne” 3(2013) 8, s. 169. 
uwagę na czynniki zmniejszające wystąpienie negatywnych skutków migracji w przypadku relacji małżeńskich i rodzinnych emigrantów.

Kiedy mówimy o przyczynach migracji i rozstaniu z rodziną, ważne jest uwzględnienie wydarzeń związanych $\mathrm{z}$ opuszczeniem rodzinnego kraju oraz bliskich osób. Możemy tu mówić o trzech kategoriach migracji, z których każda pociąga inny poziom obciążenia psychicznego i odmienny rodzaj konsekwencji dla każdej osoby i całego systemu rodzinnego. Można je opisać w następujący sposób:

1. Migracja rozwojowa - „nie muszę, ale chcę".

2. Migracja zarobkowa - ,nie chcę, ale muszę".

3. Uchodźstwo - ,ratuję życie”.

Migracje osób o charakterze rozwojowym, związane z podniesieniem komfortu życia osobistego i rodzinnego, połączone z szansą na indywidualny rozwój członków rodziny, mają podstawy w trwającym aktualnie procesie globalizacji ${ }^{19}$. Wyjazd w kategoriach „nie muszę, ale chcę” to owoc otwartych granic i rewolucji informatycznej dających szansę na szybką komunikację i nieograniczone możliwości przemieszczania się. Przy tym rodzaju migracji, gdzie fundament rozstania nie leży w sferze ekonomicznej, osoby zmieniające miejsce zamieszkania mają większe poczucie bezpieczeństwa niż osoby wyjeżdżające ,za chlebem”. Gdy wyznaczone cele nie zostaną zrealizowane, w przypadku opisywanego rodzaju wyjazdu człowiek może powrócić do kraju w dowolnej chwili, bez większego obciążenia psychicznego. Z jednej strony traktowanie migracji $\mathrm{w}$ szerokiej perspektywie, jako czasu zbierania doświadczeń, szkolenia języka, zdobywania kwalifikacji zawodowych, czasu na zawieranie znajomości, a nie wyłącznie szansy na zarobienie pieniędzy, chroni migranta przed większymi emocjonalnymi konsekwencjami ewentualnych niepowodzeń. Z drugiej jednak nieumiejętność wybierania spośród wielu możliwości zarówno przez niego, jak i przez całą rodzinę, może powodować poczucie zagubienia, straty czasu, doprowadzić do postawy bierności i braku poczucia sensu życia ${ }^{20}$.

Wyjazd ,pod presją" stanowi większe zagrożenie dla życia psychicznego osób niż rozstanie nieuwikłane w kontekst biedy, choroby, presji społecznej czy trudności w relacjach małżeńskich. W przypadku migracji o charakterze zarobkowym, którą można opisać jako „nie chcę, ale muszę”, pojawiające się

19 Por. E. Polak, Migracje osób w czasach globalizacji, w: Współczesne migracje ludności w Polsce-uwarunkowania i skutki, red. I. Sobczak, Gdańsk 2010, s. 53n.

${ }^{20}$ Por. A.I. Brzezińska, J. Matejczuk, Psychologiczne konsekwencje (euro)sieroctwa: styl życia rodziny, diagnoza, wsparcie, „Studia Edukacyjne” (2011)17, s. 74. 
napięcie emocjonalne i stres związany z rozłąką z najbliższymi są wyższe niż w przypadku wcześniej opisanej migracji nastawionej na rozwój. Przymus wyjazdu związany z potrzebą pozyskania środków materialnych na godne życie w kraju i konieczność podjęcia ryzyka rodzić może u migrantów poczucie niepewności, lęk przed poniesieniem porażki, objawy somatopsychiczne ${ }^{21}$, apatię, zniechęcenie, a nawet depresję. System rodziny narażony jest na wysokie ryzyko zmian, z którymi obie strony, zarówno rodzice, jak i dzieci, mogą sobie nie poradzić. Na dorosłych może również ciążyć poczucie misji „uratowania rodziny" od biedy i zapewnienia członkom rodziny godnego życia. Może to stanowić dodatkowe obciążenie psychiczne skutkujące podejmowaniem prac ryzykownych i niebezpiecznych czy też podporządkowaniem się pracodawcy i podjęciem zatrudnienia na niekorzystnych warunkach: pracą nielegalną, nienormowanymi godzinami zatrudnienia, zgodą na złe warunki socjalne ${ }^{22}$. Psychologiczne skutki migracji zarobkowej będą zależeć od: zdolności adaptacyjnych migranta, które pozwolą przystosować się mu do nowego środowiska, gotowości do radzenia sobie z nowymi wyzwaniami i zagrożeniami, wyznawanym systemem wartości czy też jakością relacji społecznych z rodziną, a także sąsiadami, pracodawcą i nowymi współpracownikami. Szczególnie inne osoby mogą stanowić dla migranta system wsparcia lub stać się dodatkowym obciążeniem, a oczekująca i kochająca rodzina będzie ułatwiała radzenie sobie z nowymi wyzwaniami. Przypuszczalnie wyjazd osób o niskim statusie społecznym, niemających jasno określonej wizji i planów na życie, krótkoterminowa perspektywa pobytu oraz zawężenie obszaru migracji wyłącznie do sfery zarobkowej najpoważniej zwiększają ryzyko niepowodzeń zarówno migrantów, jak i pozostającej w kraju rodziny ${ }^{23}$.

Migracja ratująca życie w przypadku wojen i konfliktów zbrojnych stanowi odmienny rodzaj rodzinnej destabilizacji. Opuszczenie własnego kraju nie jest sprawą związaną z chęcią rozwoju, zmiany stylu czy poziomu życia, lecz jest podyktowana potrzebą ratowania życia swojego, a także swoich bliskich. Ten typ migracji zwany uchodźstwem może prowadzić do: wyczerpania psychicznego powodowanego lękiem przed śmiercią, naruszenia podstawowej potrzeby psychicznej, jaką jest poczucie bezpieczeństwa, braku jasnych perspektyw dotyczących przyszłości, niemożności zapewnienia swojej rodzinie bezpiecznej i komfortowej przestrzeni do życia. Jednocześnie dzielenie opisywanej sytuacji z innymi członkami rodziny może powodować scalenie i po-

${ }^{21}$ Por. B. Rożnowski, D. Bryk, Stres emigracji zarobkowej i jego konsekwencje dla systemu wartości migrantów, w: Migracja - wyzwanie XXI wieku, red. M.S. Zięba, Lublin 2008, s. 152.

22 Por. S. Kozak, Patologia eurosieroctwa w Polsce. Skutki migracji zarobkowej dla dzieci i ich rodzin, Warszawa 2010, s. 125-126.

${ }^{23}$ Por. A.I. Brzezińska, J. Matejczuk, Psychologiczne konsekwencje (euro)sieroctwa, dz. cyt., s. 81 . 
głębienie więzi rodzinnych, umożliwić wsparcie w trudnych, ekstremalnych sytuacjach. Bagaż trudnych doświadczeń dzielony i niesiony razem jest lżejszy i łatwiejszy do podjęcia ${ }^{24}$.

\section{Rodzina w sytuacji migracji}

Rodzina to podstawowe środowisko rozwoju każdego człowieka. Budowane w niej relacje zarówno pomiędzy małżonkami, rodzicami i dziećmi, jak i rodzeństwem stanowią źródło wiedzy na temat siebie i otaczającego świata, dają szansę na zbieranie doświadczeń, uczenie się wartości i zasad współżycia $\mathrm{z}$ innymi ${ }^{25}$. Dla właściwego rozwoju dzieci we wszystkich sferach ich życia, a także ich wychowania ważna jest obecność rodziców będących bezpieczną bazą dla ich poszukiwań poznawczych, nabywania nowych kompetencji czy doskonalenia posiadanych zasobów. Nagłe pozbawienie fundamentu rodzicielskiej opieki istotnie zaburza właściwy rozwój fizyczny, emocjonalny i społeczny dzieci. W sytuacji migracji rodziców czy też całej rodziny dziecko jako pełnoprawny jej członek domaga się także prawa do wspólnego decydowania o własnym losie, szczególnie że kontekst wyjazdu w sposób istotny zaburza dotychczasowy styl i sposób życia. W przypadku migracji destabilizacja rodziny będzie tym większa, im mniejszy będzie wpływ poszczególnych jej członków. Taka „wspólna zgoda” oraz refleksja pozwalająca znaleźć sens czasowej rozłąki dla wszystkich członków systemu rodzinnego obniża poziom napięcia emocjonalnego, a także psychologiczne i wychowawcze konsekwencje związane z czasem rozstania. Poza tym daje szansę określenia czasu trwania nieobecności osoby opuszczającej rodzinę, planowania terminów spotkań, np. wspólnych wakacji, pozwala na wzrost świadomości dotyczącej wspólnej odpowiedzialności za rodzinę ${ }^{26}$ oraz znalezienia przez każdą z osób szansy na zdobywanie i rozwijanie osobistych kompetencji, np. naukę języka, poznawanie innych kultur, podróże, zawieranie nowych znajomości. Stanowi to istotny zysk w sytuacji konieczności dłuższego rozstania. Brak poczucia istotności i sensu nadanego przez poszczególnych członków rodziny może doprowadzić do sytuacji niepokoju, lęku, szczególnie gdy chodzi o dzieci najmłodsze i naj-

${ }^{24}$ Por. M. Kawczyńska-Butrym, Migracje - zmiany polożenia społecznego, w: Migracja wyzwanie XXI wieku, dz. cyt., s. 28.

${ }_{25}$ Por. W. Danilewicz, Sytuacja życiowa dzieci w rodzinach migracyjnych, Białystok 2006, s. 34 .

${ }^{26}$ Por. E. Kozdrowicz, Psychopedagogiczne skutki rozłaki migracyjnej, w: Szkoła wobec mobilności zawodowej rodziców i opiekunów, red. E. Kozdrowicz, B. Walczak, Warszawa 2008, s. 23, https://bezpiecznaszkola.men.gov.pl/wp-content/uploads/2015/09/zeszyt_8_all.pdf [dostęp: 9.10.2016]. 
słabsze $^{27}$. Czynnik ryzyka pojawiających się nieprawidłowości będzie wyższy w przypadku dzieci młodszych, u których procesy poznawcze znajdują się na niższym poziomie. Niemożność włączenia własnej opcji $\mathrm{w}$ rodzinny dialog może wywołać u małoletnich poczucie opuszczenia, a nawet porzucenia ${ }^{28}$. Po pierwsze, nie są one w stanie być czynnymi uczestnikami procesu rozstania, czyli wspólnych decyzji dotyczących wyjazdu. Po drugie, relacja rodzicdziecko na wczesnym etapie życia ma bardziej wiążący i znaczący charakter z punktu widzenia rozwojowego. Wychowanie dziecka bazuje na naśladowaniu rodzica jako najlepszego i najważniejszego autorytetu. W przypadku jego braku dziecko może czuć się zagubione. Brak bezpiecznej bazy ogranicza zdolność do swobodnego eksplorowania rzeczywistości, otwartość wobec nowych wyzwań, łatwość nawiązywania relacji. Dzieci starsze potrafią lepiej zintegrować poznawczo zaistniałą sytuację. Mają zdolność wytłumaczenia sobie potrzeby wyjazdu rodzica, mogą widzieć w tym również dla siebie pozytywne konsekwencje i choć brak osoby kochanej nie jest bez znaczenia dla ich codziennego funkcjonowania, różne formy kontaktu, np. Skype, telefon itp., mogą obniżać ryzyko wystąpienia negatywnego wpływu rozłąki ${ }^{29}$.

Badania wskazują, że skutki związane $\mathrm{z}$ nieposiadaniem przez dzieci i młodzież jednego lub obojga rodziców z powodu ich wyjazdu za granicę, co współcześnie określa się mianem eurosieroctwa ${ }^{30}$, są istotnie wyższe w sytuacji, gdy jeden lub oboje z rodziców są zmuszeni z uwagi na sytuację ekonomiczną do opuszczenia domu i pozostawienia dzieci, a ich wyjazd można zakwalifikować do kategorii „nie chcę, ale muszę”. Ograniczony system kontroli rodzicielskiej oraz doświadczenie samotności, braku opieki i pomocy może prowadzić do obniżenia wyników szkolnych, pojawiania się aktów agresji, niekontrolowanych wybuchów złości czy gniewu bądź wycofania z życia społeczności rówieśniczej ${ }^{31}$. U dzieci i nastolatków może mieć miejsce proces idealizacji nieobecnego rodzica. Najczęściej dotyczy to osoby ojca, który widziany jest jako ten bardziej kochający i dający więcej swobody ${ }^{32}$. Głębo-

${ }^{27}$ Por. A.I. Brzezińska, J. Matejczuk, Psychologiczne konsekwencje (euro)sieroctwa, dz. cyt. s. 82.

${ }^{28}$ Por. W. Danilewicz, Sytuacja życiowa dzieci w rodzinach migracyjnych, dz. cyt., s. 170.

${ }^{29}$ Por. W. Danilewicz, Sytuacja życiowa dzieci w rodzinach migracyjnych, dz. cyt., s. 127.

30 Por. S. Kozak, Patologia eurosieroctwa w Polsce. Skutki migracji zarobkowej dla dzieci i ich rodzin, Warszawa 2010, s. 113.

${ }^{31}$ Por. M. Kawczyńska-Butrym, Migracja: Perspektywa mikrospołeczna - indywidualne i rodzinne zyski, koszty i straty, w: Migracja - wyzwanie XXI wieku, dz. cyt., s. 110; B. Walczak, Migracje rodzicielskie, w: Szkoła wobec mobilności zawodowej rodziców i opiekunów, dz. cyt., s. 19, https://bezpiecznaszkola.men.gov.pl/wpcontent/uploads/2015/09/ zeszyt_8_all.pdf [dostęp: 9.10.2016]; S. Kozak, Patologia eurosieroctwa w Polsce. Skutki migracji zarobkowej dla dzieci i ich rodzin, Warszawa 2010, s. 124.

32 Por. B. Walczak, Migracje rodzicielskie, w: Szkoła wobec mobilności zawodowej rodziców $i$ opiekunów, dz. cyt., s. 17, https://bezpiecznaszkola.men.gov.pl/wpcontent/uploads/2015/09/ 
kie doświadczenie braku rodzica może także powodować zachowania skrajne, przekreślające ważność rodzica nieobecnego, czyniące go postacią nierealną̧3 Opisane zachowania uzależnione będą od poziomu i jakości więzi rodzinnych. Sytuacja ta może być wywołana zarówno rozstaniem i niezdolnością zrozumienia „nowej” sytuacji, pozwalającej na odczytanie jej jako szansy dla siebie i całej rodziny, jak i problemami, które miały miejsce wcześniej i przyczyniły się do wyjazdu jednego z rodziców.

Szczególnie trudna sytuacja ma miejsce w przypadku wyjazdu obu rodziców i pozostawienia dzieci pod opieką dalszej rodziny, np. dziadków. Migracja podwójna, gdy mamy do czynienia z naprzemiennym wyjazdem rodziców czy też wyjazdem równoczesnym, powoduje głębokie zmiany w strukturze osobowej, gdyż skutkuje zaburzeniami w obszarze fundamentalnym dla rozwoju psychicznego i społecznego, jakim jest poczucie stabilizacji i bezpieczeństwa $^{34}$. Amplituda pojawiających się dysfunkcji będzie prawdopodobnie zależała od jakości opieki sprawowanej nad dzieckiem przez rodzica czy opiekuna pozostającego z dzieckiem. Przedstawiana przez nich interpretacja migracji jednego lub obu rodziców będzie miała znaczenie dla jakości relacji z dziećmi czy wnukami. Może się ona wyrażać współczuciem powodującym troskę, zainteresowanie, dającym poczucie bezpieczeństwa i pomoc, może jednak wyrażać się w niechęci do pozostawionych małoletnich, brakiem kompetentnej opieki spowodowanej przymusem i koniecznością. Taki sposób odnoszenia się do dzieci może sprawić, że będą doświadczały poczucia zagubienia, osamotnienia, braku poczucia wpływu na własne życie, bierności w kontaktach z innymi, będą wybierały niekonstruktywne sposoby radzenia sobie czy też czuły się uprzedmiotowione ${ }^{35}$. Im dziecko młodsze, tym większa potrzeba bliskości, czułości, zauważenia, docenienia, pomocy. Samotny rodzic, nadmiernie obciążony obowiązkami zawodowymi i domowymi może nie mieć wystarczającej ilości czasu dla swoich dzieci. Jego siły fizyczne także mogą się wyczerpać, co może znacznie obniżyć poziom i jakość kontaktu z potomstwem. Badania wskazują, że matki przejmujące odpowiedzialność za wychowanie dzieci podczas migracji ojców przejmują role kulturowo zarezerwowane dla mężczyzny jako głowy rodziny. W ten sposób zachowany zostaje jednak system kontroli i adekwatny do wieku dzieci poziom ich socjalizacji ${ }^{36}$.

zeszyt_8_all.pdf, [dostęp: 9.10.2016].

${ }^{33}$ Por. E. Kozdrowicz, Psychopedagogiczne skutki rozłaki migracyjnej, dz. cyt., s. 25.

${ }^{34}$ Por. B. Walczak, Migracje rodzicielskie, w: Szkoła wobec mobilności zawodowej rodziców i opiekunów, dz. cyt., s. 20, https://bezpiecznaszkola.men.gov.pl/wp-content/uploads/2015/09/zeszyt_8_all.pdf, [dostęp: 12.10.2016].

${ }^{35}$ Por. A.I. Brzezińska, J. Matejczuk, Psychologiczne konsekwencje (euro)sieroctwa, dz. cyt. S. 83.

${ }^{36}$ Por. B. Walczak, Migracje rodzicielskie, w: Szkoła wobec mobilności zawodowej rodziców i opiekunów, dz. cyt., s. 19. 


\section{Pomoc rodzinie w sytuacji migracji}

Nie ma możliwości wyeliminowania wszystkich negatywnych skutków rozłąki między małżonkami oraz rodzicami i dziećmi. Należy jednak dążyć do tego, aby ich konsekwencje były jak najmniejsze, a oprócz strat rozstanie stało się źródłem zasobów i psychologicznych zysków.

Tym, co w pierwszej kolejności powinno chronić rodzinny system przed rozpadem czy rozluźnieniem więzi między jej członkami, jest panujący w nim jednoznaczny system wartości. Pozwala on postawić dobro rodzinne ponad dobrem jednostkowym, włączać w dialog wszystkie osoby, uwzględniać ich racje, a także uczyć gotowości do poświęceń. Osoby dorosłe podejmujące decyzję o migracji powinny charakteryzować się dojrzałością pod względem psychospołecznym, mieć odpowiednie kompetencje intelektualne i społeczne oraz dojrzałość emocjonalną wyrażającą się w empatii, zrozumieniu sytuacji drugiej osoby, uwzględnieniu wszystkich opcji ,za i przeciw”. Może to uchronić rodzinę przed dezintegracją, dając każdej osobie szansę na lepszy i właściwy dla niej rozwój ${ }^{37}$. Należy tu zauważyć, że rodzaj podjętej decyzji oraz dostrzeganie wielowymiarowości możliwych konsekwencji będą prawdopodobnie zależały od systemu przekonań danej osoby ${ }^{38}$, czyli sposobu, $w$ jaki interpretuje ona pojęcie małżeństwa, rodziny, ale także indywidualnego rozwoju, wykorzystania życiowych ofert i pojawiającego się ryzyka. Konsolidacja wspomnianych przekonań, uwzględniająca płaszczyzny ,ja”, „my” i „wy”, pozwala podejmować decyzje, które w ostateczności mogą stać się źródłem zasobów dla jej członków lub skutkować większą lub mniejszą destabilizacją rodziny. Tak więc decyzja o migracji powinna być poprzedzona refleksją dotyczącą jej znaczenia dla wszystkich osób w rodzinie, powinna być podjęta świadomie i uwzględniać czas na przygotowanie do nowej sytuacji zarówno dorosłych, jak i dzieci ${ }^{39}$.

Rodzaj i jakość opieki nad dzieckiem przebywającym bez rodzica ma również istotne znaczenie dla systemu rodzinnego. Jak już wspomniano, opuszczenie rodzinnego domu przez jednego lub oboje rodziców powoduje w pierwszej kolejności delegowanie ich dotychczasowej roli na pozostałych członków rodziny. $Z$ jednej strony stwarza to zagrożenie przeciążenia nowymi obowiązkami, z drugiej jednak daje szansę na pogłębienie więzi z rodzicem czy opiekunem. Dom może stać się dla wszystkich miejscem nauki odpowiedzialności

37 Por. A.I. Brzezińska, J. Matejczuk, Psychologiczne konsekwencje (euro)sieroctwa, dz. cyt., s. 75.

38 Por. A.I. Brzezińska, R. Kaczan, L. Rycielska, Przekonania o swoim życiu. Spostrzeganie historii życia przez osoby z ograniczeniami sprawności, Warszawa 2010, s. 17.

39 Por. A.I. Brzezińska, J. Matejczuk, Psychologiczne konsekwencje (euro)sieroctwa, dz. cyt., s. $75 \mathrm{n}$. 
za siebie i innych. Dzieci starsze mogą uczyć się samodzielności poprzez wykonywanie różnego rodzaju czynności, np. dbanie o porządek w domu, pomoc w zakupach, opiekę nad rodzeństwem itp. Wzrost odpowiedzialności adekwatny do wieku rozwojowego i możliwości dziecka może pozytywnie wpłynąć na jego dalszy stosunek do obowiązków zawodowych, małżeńskich i rodzinnych. Włączenie dzieci w świadome planowanie czasu i obowiązków domowych może budować także otwartość na potrzeby innych i empatię. Istotne jest więc dojrzałe zaplanowanie tego ,,innego czasu”, zauważenie w nim korzyści i potraktowanie go jako okazji do nauki. Ważne jest, aby pamiętać, że dzieci nie mogą przejąć roli dorosłego, którego nie ma w domu. Muszą mieć czas na naukę, zabawę, rozwój własnych talentów ${ }^{40}$.

Równie ważnym czynnikiem pomagającym uniknąć negatywnych konsekwencji rozłąki pomiędzy małżonkami, a także rodzicami i dziećmi stanowi częstotliwość spotkań rodziny w trakcie migracji. Im spotkania będą częstsze i będą bardziej sprzyjały rozwojowi bliskich więzi, tym większa szansa, że etap życia, w którym rodzina nie mieszka razem, nie wniesie w jej życie rozwojowo istotniejszych zmian. Nie chodzi więc o to, aby wracając do domu, ojciec czy matka przywozili dla dzieci zabawki, lecz po wcześniejszym zaplanowaniu spędzali z nimi swój czas na rozmowach, wycieczkach, grach, wspólnych posiłkach czy niedzielnej Eucharystii i modlitwie. Warto wspomnieć, że ryzyko rozpadu małżeństwa i rodziny jest odwrotnie proporcjonalne do poziomu bliskości małżonków przed wyjazdem. Oznacza to, że szansa scalenia rodziny, która przed wyjazdem przeżywa kryzys, jest niewielka. Wprost przeciwnie, rozłąka może pogłębić dysfunkcję istniejącą już w rodzinie i doprowadzić do jej rozpadu ${ }^{41}$.

\section{Teologiczne i duszpasterskie spojrzenie na problem migracji}

Kolejną istotną sferą życia człowieka jest jego system wartości i wierzeń. Ma on wpływ na światopogląd osoby. Wydaje się, że należy również podjąć temat opieki sakramentalnej i duszpasterskiej osób przebywających na migracji, aby nie zatraciły one tożsamości osobowej i religijnej. Wystarczy sięgnąć do swego rodzaju ,wyznacznika norm wiary”, jakim jest objawienie, by uświadomić sobie, że również teologia zajmuje się migracją.

Teologia biblijna, mówiąc o życiu człowieka i jego przemijalności, niejednokrotnie odwołuje się do obrazu pielgrzymowania. Jest on znany i czę-

40 Por. E. Kozdrowicz, Psychopedagogiczne skutki rozłąki migracyjnej, dz. cyt., s. 20; W. Danilewicz, Sytuacja życiowa dzieci w rodzinach migracyjnych, dz. cyt., s. 167.

${ }^{41}$ Por. E. Kozdrowicz, Psychopedagogiczne skutki rozłaki migracyjnej, dz. cyt., s. 21. 
sto przywoływany podczas prób ukazania przemijalności oraz tymczasowości ludzkich planów. Można zaryzykować stwierdzenie, że według Biblii u podstaw ruchów migracyjnych stoi metaforyczny obraz „wieży Babel”. Nawiązuje on do ludzkiej pychy jako czynnika rozłamu pomiędzy biblijnymi pokoleniami ludzkości popotopowej. Pierwsza wzmianka o wędrówce związanej z przesiedleniem się ludzi znajduje się w Księdze Rodzaju. Opisuje ona m.in. dzieje Teracha (zob. Rdz 11,31) ukazuje przesiedlenie się całej jego rodziny z ,ziemi rodzinnej” do Ur Chaldejskiego, do Charanu. Czytając dalsze opisy biblijne, zauważymy, że kolejnym migrantem był jeden $\mathrm{z}$ synów Teracha Abraham (zob. Rdz 12,4n). Wędrował on do Sychem - w którym ówcześnie mieszkali Kananejczycy.

Jednak najbardziej znanym motywem migracyjnym pozostaje wciąż historia Izreala (rozumianego jako naród), zwłaszcza jego czterdziestoletnia wędrówka z Egiptu do Ziemi Obiecanej (zob. Rdz 11,10n). Księga Kapłańska przypomina o tym, że ziemia została dana człowiekowi jedynie w czasowe władanie: „Ziemia należy do Mnie, a wy jesteście u Mnie przybyszami i osadnikami” (Kpł 25,23). W ten sposób był kształtowany obraz niebieskiej ojczyzny, miejsca, z którego człowiek pochodzi i do którego ostatecznie zmierza (por. 1 P 2,11). Teza ta została niejednokrotnie potwierdzona przez nauczanie Kościoła. Także teksty starożytne, jak np. fragment Listu do Diogneta, zatytułowany: „Chrześcijanie w świecie” zawiera następującą treść: „Chrześcijanie nie różnią się od innych ludzi ani miejscem zamieszkania, ani językiem, ani strojem. Nie mają bowiem własnych miast, nie posługują się jakimś niezwykłym dialektem, ich sposób życia nie odznacza się niczym szczególnym [...]. Mieszkają każdy we własnej ojczyźnie, lecz niby obcy przybysze [...]. Przebywają na ziemi, lecz są obywatelami nieba [...]"42.

Po przywołaniu kilku cytatów z Pisma Świętego możemy zauważyć, że podstawowy podział zjawisk migracyjnych w kontekście biblijnym dotyczy często sfery wolitywnej. Najprostsza klasyfikacja pojęciowa migracji ukaże ją jako: dobrowolną, ekonomicznie konieczną ${ }^{43}$ lub przymusową. O ile pierwszy typ wiąże się z czynnikami pozytywnymi, takimi jak samorozwój, chęć wzbogacenia, zapewnienia lepszego bytu rodzinie, o tyle trzeci ma zasadniczo wydźwięk negatywny, jest wynikiem wojen i prześladowań ${ }^{44}$.

42 List do Diogneta nr 5-6, w: Liturgia godzin, t. 2, Poznań 1984, s. 658.

${ }^{43}$ Dla przykładu: poszczególne rody biblijne opuszczały swoją ziemię rodzinną, ponieważ nie była ona w stanie zapewnić im wszystkim bytu - pożywienia, miejsca do wypasu bydła i upraw.

44 Źródła historyczne dowodzą, że jedną z kar za wyznawanie religii chrześcijańskiej w starożytnym Rzymie (zwłaszcza w przypadku kobiet) było wygnanie na pustynię - jest to przykład migracji narzuconej z powodu prześladowań; zob. Cyprianus, Ep. LXXX 1, PSP I, s. 306, za: M. Wysocki, Eschatologia okresu prześladowań na podstawie pism Tertuliana i Cypriana, Lublin 2010, s. 259. 
Współcześnie migracja jest złożonym problemem społecznym, ponieważ ze względu na region występowania (chociażby podział kontynentalny) przybiera różną formę i ma w założeniach inne cele. Nietrudno wnioskować, że z czasem problem, który początkowo wydawał się wyłącznie polityczny, stał się przedmiotem troski duszpasterskiej. W celu skoordynowania działań przy kurii rzymskiej powołano dykasterię, która zajęła się duszpasterstwem migrantów i osób podróżujących ${ }^{45}$. W 1969 roku Stolica Apostolska wydała krótkie wskazania $\mathrm{w}$ formie motu proprio odnoszące się do kwestii związanych z migracjami. Podpisany przez Pawła VI dokument Pastoralis migratorum cura jest swego rodzaju instrukcją duszpasterską dotyczącą migrantów. $\mathrm{Na}$ pierwszy plan wysuwa ona konieczność podjęcia inicjatyw związanych $\mathrm{z}$ duszpasterstwem w języku, w którym „wyrażają swoje myśli, swoją mentalność i swoje życie religijne"46.

Migrację w ujęciu personalistycznym ukazał Jan Paweł II. Odniósł ją do sytuacji rodziny, która zazwyczaj staje się głównym podmiotem negatywnych skutków omawianego zjawiska. Bardzo szczegółowo i wieloaspektowo samo zjawisko oraz stanowisko Kościoła wobec niego zostało przedstawione w orędziach na Światowy Dzień Migranta i Uchodźcy ${ }^{47}$. Migracji związanej z poszukiwaniem lub zmianą pracy Jan Paweł II poświęcił fragment w ostatniej IV części - Encykliki Laborem exercens. W dokumencie tym papież wskazał na bardzo ważny aspekt, związany z pewnym zagrożeniem moralnym, które może towarzyszyć procesom migracyjnym. Jan Paweł II uwrażliwia - ,trzeba uczynić wszystko [...] ażeby to [...] nie pociągnęło za sobą większych szkód $w$ znaczeniu moralnym, [...] by - o ile możności - przyniosło nawet dobro w życiu osobistym, rodzinnym i społecznym emigranta, zarówno gdy chodzi o kraj, do którego przybywa, jak też o ojczyznę, którą opuszcza" (LE 23). Widzimy, że dokonanie jednoznacznej oceny etycznej czy moralnej zjawiska mi-

45 W 1970 r. na mocy motu proprio Apostolicae caritatis Paweł VI ustanowił Papieską Komisję ds. Duszpasterstwa Migrantów i Podróżnych. Na mocy konstytucji Pastor Bonus (określającej kompetencje Sekretariatu Stanu, Kongregacji, Trybunałów, Rad Papieskich, innych organów administracyjnych oraz komisji w Kurii Rzymskiej. Dokument ustanawia także normy wizyt biskupów w Rzymie w formie ad limina apostolorum, a także uszczegóławia relacje między Stolicą Apostolską a Kościołami partykularnymi i konferencjami episkopatów), wydanej 28 czerwca 1988 r. papież Jan Paweł II po reformie Kurii Rzymskiej podniósł komisję do rangi Papieskiej Rady i nadał jej obecną nazwę, która w pełni brzmi: „Papieska Rada ds. Duszpasterstwa Migrantów i Podróżujących”; zob. F. Lempa, Kompetencje, uprawnienia i obowiązki w Kościele katolickim, Białystok 2013, s. 113-114; por. Jan Paweł II, Apostolic Constitution Pastor Bonus, art. 149-151, http://cef97.ulinks.net [dostęp: 14.10.2016]; E. Sztaforski, Kuria rzymska Jana Pawła II, „Prawo Kanoniczne" 33/1-2(1990), s. 70.

46 Paweł VI, Pastoralis migratorum cura, http://daa.pl/3HQ [dostęp: 15.10.2016].

${ }^{47}$ Przytoczenie całego nauczania Kościoła dotyczące tej kwestii znacznie wykroczyłoby za ramy tej publikacji, dlatego autorzy skupili się wyłącznie na najistotniejszych wypowiedziach ostatnich trzech papieży dotyczących migracji w kontekście życia rodzinnego. 
gracji nie jest proste. Wynika to $\mathrm{z}$ wielu czynników wchodzących w skład tego zjawiska. Pomimo że człowiek ma prawo do migrowania, należy pamiętać, że jest to prawo drugorzędne. Pierwsze miejsce musi zajmować zawsze prawo człowieka do godnego życia ${ }^{48}$. Troskę o to papież powierza także poszczególnym instytucjom Kościoła, które jako ,jedna rodzina Boża” winny otaczać troską potrzebujące siostry i braci ${ }^{49}$.

Tematykę migracji podjął także papież Benedykt XVI. W Orędziu na Światowy Dzień Migranta i Uchodźcy w 2011 roku ukazał postać św. Pawła Apostoła, który stał się migrantem ,z powołania Bożego”. To dzięki tej postawie świętego Kościół przybrał formę, którą widzimy po dzień dzisiejszy. Benedykt XVI zwrócił uwagę na pozytywny wpływ migracji na proces budowania rodziny ludzkiej. Mówi on o tworzeniu kulturowych i ekonomicznych pomostów, których głównym przęsłem stają się ośrodki naukowe oraz uczący się w nich młodzi ludzie, poznający się poprzez współpracę ,pomiędzy swoimi ojczyznami i krajami udzielającymi im gościny, a wszystko to zmierza właśnie w kierunku stworzenia «jednej rodziny ludzkiej» [...]. W szkole i na uniwersytecie kształtuje się kultura nowych pokoleń, których zdolność postrzegania ludzkości jako jednej rodziny, powołanej do jedności w różnorodności zależy od tych właśnie instytucji” ${ }^{50}$. Natomiast w Orędziu na Światowy Dzień Migranta i Uchodźcy w 2013 roku podkreślił (mówiąc o migracji w kontekście rodziny), że Kościół nie może ograniczyć się tylko i wyłącznie do opieki duszpasterskiej, lecz musi dążyć do zapewnienia holistycznej pomocy, która przejawia się poprzez wsparcie w asymilacji, pomoc socjalną i materialną, zwłaszcza w pierwszym okresie migracyjnym ${ }^{51}$. Kościół zachęca do pełnienia dzieł miłosierdzia wobec migrantów, których dotknęła trudna sytuacja ekonomiczna i polityczna.

W nieco innym ujęciu temat migracyjny, kładąc akcent na migracje w kontekście przymusowego uchodźstwa, poruszył także papież Franciszek podczas

48 Mówiąc „godnego”, mamy tu namyśli stworzenie takich warunków socjalnych i pracowniczych, które odpowiadają średniej kraju, w którym dana osoba mieszka i pracuje; por. Papieska Rada ds. Duszpasterstwa Migrantów i Podróżujących i Papieska Rada Cor unum, Przyjęcie Chrystusa w uchodźcach i przymusowo przesiedlanych. Wytyczne duszpasterskie, Watykan 2013, http://daa.pl/3Js [dostęp: 15.10.2016].

49 Zob. Papieska Rada ds. Duszpasterstwa Migrantów i Podróżujących i Papieska Rada Cor unum, Przyjęcie Chrystusa w uchodźcach i przymusowo przesiedlanych. Wytyczne duszpasterskie, Watykan 2013, http://daa.pl/3Js [dostęp: 15.10.2016]; Jan Paweł II, Na ziemi pokój ludziom, których Bóg mituje! Orędzie na Światowy Dzień Pokoju 2000, Watykan 2000, pkt. 13, http://daa.pl/3Ju [dostęp: 15.10.2016].

50 Zob. Benedykt XVI, Migracje: pielgrzymka wiary i nadziei. Orędzie na Światowy 97 Dzień Migranta i Uchodźcy $2011 \mathrm{roku}$, http://daa.pl/3Jw [dostęp: 15.10.2016].

${ }^{51}$ Zob. Benedykt XVI, Migracje: pielgrzymka wiary i nadziei. Orędzie na Światowy Dzień Migranta i Uchodźcy 2013 roku, http://daa.pl/3Jt [dostęp: 15.10.2016], zob. Jan Paweł II, Na ziemi pokój..., dz. cyt., pkt 14. 
wizyty w Polsce w 2016 roku. Apelował wówczas o miłosierdzie i rozważne decyzje względem osób, które ze względu na niebezpieczeństwo grożące im $\mathrm{w}$ ich rodzimych krajach potrzebują pomocy ${ }^{52}$. Mówiąc o problemach migracji i przymusowej emigracji, papież zwrócił uwagę na konieczność „,współpracy i koordynacji na poziomie międzynarodowym, w celu znalezienia rozwiązania konfliktów i wojen, które zmuszają wielu ludzi do opuszczenia swoich domów i ojczyzny" 53 , dzięki temu będzie można świadczyć „konkretnymi faktami o wartościach humanistycznych i chrześcijańskich"54.

Rodzina jako najmniejsza grupa społeczna podlega szczególnej opiece, co dostrzec możemy zarówno w kontekście prawa cywilnego, jak i szeroko rozumianej troski Kościoła katolickiego o małżeństwo i rodzinę. Poszczególni członkowie klanów są jednak odrębnymi istotami - mają własną niepowtarzalną tożsamość, która czyni ich ludźmi wyjątkowymi, takimi jakimi chciał ich Bóg. Interdyscyplinarna naukowa refleksja na ten temat umożliwia holistyczne podejście do niesienia pomocy drugiemu człowiekowi, zarówno gdy chodzi o asymilację (pomoc prawną), właściwe odniesienie do siebie i sytuacji, w jakiej zostało się osadzonym (pomoc psychologiczna), oraz właściwe przeżycie czasu odizolowania od najbliższych lub ojczystego kraju dzięki odniesieniu się do wartości uniwersalnych i ponadczasowych (pomoc duszpasterska). Owo podejście pomaga także dostrzegać pozytywne wymiary migracji, które często pozostają $\mathrm{w}$ ukryciu, zwłaszcza $\mathrm{w}$ przypadku pozostawienia rodziny i dotychczasowego środowiska życia w związku z próbą polepszenia sytuacji ekonomicznej. Usystematyzowane i konkretne podejście do migrantów przymusowych pozwala na szybsze zaaklimatyzowanie się ich i odnalezienie w nowej rzeczywistości, w której przyszło im żyć.

Z uwagi na integralność istoty ludzkiej należy troszczyć się o nią we wszystkich wymiarach życia, począwszy od widocznego - fizycznego, przez wymiar psychiczny, społeczny, a także duchowy. Masowe migracje są ogromnym wyzwaniem dla różnych nauk, nie tylko z powodu prób wypracowywania teoretycznych schematów, ale przede wszystkim praktycznych rozwiązań. Uwzględniając omawiane $\mathrm{w}$ artykule obszary, należy przede wszystkim uświadamiać migrantom pozytywne i negatywne skutki długoterminowej rozłąki z rodziną.

52 Por. Franciszek, Przemówienie podczas pielgrzymki do Polski, Kraków-Wawel, 27 lipca $2016 \mathrm{r}$.

${ }^{53}$ Franciszek, Przemówienie podczas pielgrzymki do Polski, Kraków-Wawel, 27 lipca 2016 r.; zob. także: Jan Paweł II, Na ziemi pokój ..., dz. cyt., pkt 18.

54 Tamże. 
Jednocześnie migrant i jego bliscy powinni doświadczać ochrony zarówno ze strony państwa, do którego się udaje, jak i tego, które opuszcza. W związ$\mathrm{ku} \mathrm{z}$ tym, że rozłąka pociąga za sobą duże napięcie psychiczne, ważne jest, aby osoba opuszczająca rodzinny dom miała poczucie, że niezależnie od zaistniałej na obczyźnie sytuacji, zawsze jest oczekiwana i potrzebna w domu i we własnym kraju, a jej los i bliskim, i instytucjom państwowym nie jest obojętny. Właściwe podejście psychologiczne oraz umiejętne interpretowanie prawa dotyczącego migrantów i ich rodzin sprawia, że człowiek z jednej strony, pomimo sytuacji, w jakiej się znalazł, może utwierdzić się w swojej wyjątkowości, z drugiej jednak zauważa, że nie jest osamotniony, lecz jest częścią jednej rodziny ludzkiej. To z kolei ukazuje, jak ważne jest właściwe podejście duszpasterskie, które winno być poprzedzone właściwym rozpoznaniem sytuacji poszczególnego człowieka, jego rodzinny i właściwego dla nich kontekstu migracyjnego.

Ważne jest, aby decyzja o opuszczeniu rodziny była wspólną decyzją wszystkich jej członków. Także każdy z nich powinien w krótszym lub dłuższym rozstaniu zobaczyć i doświadczyć szansy na rozwój własnych, nowych kompetencji, zdolności, talentów. Istotne jest też precyzyjne określenie celu wyjazdu migranta za granicę oraz wyznaczenie, chociażby w przybliżeniu, daty powrotu i ewentualnych spotkań. Najmłodszym członkom rodziny należy zapewnić kompetentne wsparcie ze strony drugiego rodzica lub opiekunów, ale także pedagogów, nauczycieli i duszpasterzy. Konieczny wydaje się częsty kontakt dzieci z rodzicami, który aktualnie jest możliwy dzięki telefonom czy Internetowi. Szczególnie istotna wydaje się pomoc ze strony wspólnoty kościelnej, której zadaniem, oprócz przekazu wiary, jest dawanie poczucia jedności i wsparcia, szczególnie w sytuacji doświadczenia zagubienia i samotności. Kościół otwarty na migrantów, uwzględniający kontekst ich życia, daje także szansę na konsolidację ich tożsamości osobowej i narodowej, czyli dojrzewanie ich osobowości oraz odnajdywanie się na nowo w roli kobiet, mężczyzn, żon, mężów, rodziców i mieszkańców naszego kraju.

Migracja jest tematem rozległym, podejmowanym przez liczne nauki. Powyższe rozważania ukazały ją jako proces złożony, mający różne oblicza. Rozpatrywany w kontekście rodziny, jej sytuacji materialnej, tworzenia relacji, przekazywania wartości moralnych ${ }^{55}$ nie może zostać oderwany od prawa, podstaw psychologii i opieki duszpasterskiej. Podczas oceny zjawiska migracji oraz w trakcie wszelkich działań mających na celu pomoc migrantom należy pamiętać, że migracje często stanowią „część historii narodów i poszczególnych religii, a jednocześnie kształtują doświadczenie jednostek"

${ }^{55}$ Zob. H. Pilarczyk, Rodzina a wartości moralne. Miejsce ich nauczania, weryfikacji i realizacji, „Teologia i Moralność” nr 2(16): Rodzina-szkoła-wychowanie, 2014, s. 51-63.

${ }_{56}$ Zob. J. Krotofil, Religia w procesie ksztattowania tożsamości wśród polskich migrantów w Wielkiej Brytanii, Kraków 2013, s. 51. 
Powyższe rozważania ukazały, że należy zadbać o to, aby doświadczenie to przeżyte zostało z pełną świadomością, akceptacją i z poczuciem słuszności podjętej decyzji, które winni odczuwać migranci i ich najbliżsi - „domagają się prawa do uczestnictwa w użytkowaniu dóbr materialnych i chcą, aby wykorzystano ich zdolność do pracy w budowaniu świata sprawiedliwszego i szczęśliwszego dla wszystkich". Pozwoli to przygotować grunt dla ewangelizacji oraz pasterskiego przepowiadania ukazującego, że tutaj, na Ziemi, jesteśmy „przybyszami i osadnikami” (Kpł 25,23), dążącymi do ojczyzny, która jest w Niebie, a „podźwignięcie ubogich jest wielką szansą dla moralnego, kulturalnego, a także gospodarczego wzrostu całej ludzkości" ${ }^{\text {"57. }}$.

\section{MIGRATION IN THE CONTEXT OF PASTORAL CARE OF FAMILIES AS A CHALLENGE FOR THE MODERN CHURCH. LEGAL, PSYCHOLOGICAL AND THEOLOGICAL PERSPECTIVES}

\section{Summary}

The article is an attempt to illustrate the concept of migration and its impact on the family from three perspectives: legal, psychological and social teaching of the Catholic Church. The paper presents, inter alia, the basic legal documents which regulate the issues related to migration and the forced migration of families, psychological aspects and their impact on the functioning of a person and family as a community of individuals and discusses the basic documents and statements of selected popes regarding migration. The articles finishes with conclusions that could serve as examples of specific solutions to help a family who has experienced migration.

Słowa kluczowe: migracja; psychologia rodziny; duszpasterstwo migrantów; emigracja

Keywords: migration; psychology of family; pastoral care of migrants; immigration

\section{BIBLIOGRAFIA}

Benedykt XVI, Migracje: pielgrzymka wiary i nadziei. Orędzie na Światowy 97 Dzień Migranta i Uchodźcy $2011 \mathrm{roku}$, http://daa.pl/3Jw [dostęp: 15.10.2016].

Benedykt XVI, Migracje: pielgrzymka wiary i nadziei. Orędzie na Światowy 99 Dzień Migranta i Uchodźcy 2013 roku, http://daa.pl/3Jt [dostęp: 15.10.2016].

57 Por. Jan Paweł II, Na ziemi pokój..., dz. cyt., pkt 14. 
Brzezińska A.I., Matejczuk J., Psychologiczne konsekwencje (euro)sieroctwa: styl życia rodziny, diagnoza, wsparcie, „Studia Edukacyjne” 17(2011), s. 71-88.

Brzezińska A.I., Kaczan R., Rycielska L., Przekonania o swoim życiu. Spostrzeganie historii życia przez osoby z ograniczeniami sprawności, Warszawa 2010.

Danilewicz W., Sytuacja życiowa dzieci w rodzinach migracyjnych, Białystok 2006.

Dzięgielewski M., Spoleczne i kulturowe skutki migracji poakcesyjnej na łamach tygodników opinii w latach 2004-2012, „Studia Migracyjne” 3(2013) 8, s. 147-188.

Franciszek, Przemówienie podczas pielgrzymki do Polski, Kraków-Wawel, 27 lipca 2016 r.: https:// goo.gl/cd2Yty [dostęp: 4.10.2016].

Głowacka D., Rozporzadzenie Dublin II, http://www.refugee.artnet.pl/?mod=knowbase\&path=2834 \&PHPSESSID=349b36996e60d85b6fedb9ef930bdf89, [dostęp: 4.10.2016].

Jan Paweł II, Apostolic Constitution Pastor Bonus, art. 149-151, http://cef97.ulinks.net [dostęp: 14.10.2016].

Jan Paweł II, Na ziemi pokój ludziom, których Bóg miluje! Orędzie na Światowy Dzień Pokoju 2000, Watykan 2000, pkt. 13: http://daa.pl/3Ju [dostęp: 15.10.2016].

Jończy R., Migracje zarobkowe ludności autochtonicznej z województwa opolskiego: studium ekonomicznych determinant i konsekwencji, Opole 2003.

Kawczyńska-Butrym M., Migracja. Perspektywa mikrospołeczna - indywidualne i rodzinne zyski, koszty i straty, w: Migracja - wyzwanie XXI wieku, red. M.S. Zięba, Lublin 2008, s. 109-117.

Kawczyńska-Butrym M., Migracje - zmiany położenia społecznego, w: Migracja - wyzwanie XXI wieku, red. M.S. Zięba, Lublin 2008, s. 27-34.

Konwencja dotycząca statusu uchodźców, sporządzona w Genewie dnia 28 lipca 1951 r., Dz.U. $1991 \mathrm{nr} 119$ poz. 515.

Kozak S., Patologia eurosieroctwa w Polsce. Skutki migracji zarobkowej dla dzieci i ich rodzin, Warszawa 2010.

Kozdrowicz E., Psychopedagogiczne skutki rozłaki migracyjnej, w: Szkoła wobec mobilności zawodowej rodziców i opiekunów, red. E. Kozdrowicz, B. Walczak, Warszawa 2008, s. 23, https:// bezpiecznaszkola. men.gov.pl/ wp-content/uploads/2015/09/zeszyt_8_all.pdf [dostęp: 9.10. 2016].

Krotofil J., Religia w procesie ksztaltowania tożsamości wśród polskich migrantów w Wielkiej Brytanii, Kraków 2013.

Lempa F., Kompetencje, uprawnienia i obowiazki w Kościele katolickim, Białystok 2013.

List do Diogneta nr 5-6, w: Liturgia godzin, t. 2, Poznań 1984, s. 658.

Migracje: dzieje, typologia, definicje, red. A. Furdal, W. Wysoczański, Wrocław 2006.

Papieska Rada ds. Duszpasterstwa Migrantów i Podróżujących i Papieska Rada Cor unum, Przyjęcie Chrystusa w uchodźcach i przymusowo przesiedlanych. Wytyczne duszpasterskie, Watykan 2013: http://daa.pl/3Js [dostęp: 15.10.2016].

Paweł VI, Motu proprio Pastoralis migratorum cura.: http://daa.pl/3HQ [dostęp: 15.10.2016].

Paweł VI, Motu proprio Sollicitudo Omnium Ecclesiarum.: https://goo.gl/Fxebc2 [dostęp: 01.10.2016].

Pilarczyk H., Rodzina a wartości moralne. Miejsce ich nauczania, weryfikacji i realizacji, „Teologia i Moralność" 2(16) 2014: Rodzina - szkoła-wychowanie, s. 51-63.

Polak E., Migracje osób w czasach globalizacji, w: Wspótczesne migracje ludności w Polsce-uwarunkowania i skutki, red. I. Sobczak, Gdańsk 2010, s. 53-63.

Rozporządzenie Rady (WE) nr 343/2003 z dnia 18 lutego 2003 r. ustanawiające kryteria i mechanizmy określania państwa członkowskiego właściwego dla rozpatrywania wniosku o azyl, wniesionego w jednym z państw członkowskich przez obywatela państwa trzeciego., Dz.U. L 50 z 25.2.2003.

Rożnowski B., Bryk D., Stres emigracji zarobkowej i jego konsekwencje dla systemu wartości migrantów, w: Migracja - wyzwanie XXI wieku, red. M.S. Zięba, Lublin 2008, s. 127-152.

Sztaforski E., Kuria rzymska Jana Pawła II, „Prawo Kanoniczne” 33/1-2(1990), s. 21-80. 
Urzędowska M., Rak naszych czasów, http://wyborcza.pl/1,75968,18423725,rak-naszych-czasow. html, [dostęp: 25.08.2016].

Ustawa z dnia 12 grudnia 2013 r. o cudzoziemcach, Dz.U. 2013 poz. 1650.

Walaszek A., Migracje Europejczyków 1650-1914, Kraków 2007.

Walczak B., Migracje rodzicielskie, w: Szkoła wobec mobilności zawodowej rodziców i opiekunów, red. E. Kozdrowicz, B. Walczak, Warszawa 2008, https://bezpiecznaszkola.men.gov.pl/wpcontent/uploads/2015/09/zeszyt_8_all.pdf [dostęp: 9.10.2016].

Wróbel P., Migracje Żydów polskich. Próba syntezy, „Biuletyn Żydowskiego Instytutu Historycznego", styczeń-czerwiec 1998, nr 1/2 (185/186), s. 3-30.

Wysocki M., Eschatologia okresu prześladowań na podstawie pism Tertuliana i Cypriana, Lublin 2010.

AnNa Wieradzka-Pilarczyk - doktor nauk teologicznych, magister psychologii, pracownik naukowo-dydaktyczny Wydziału Teologicznego Uniwersytetu im. Adama Mickiewicza w Poznaniu, sekretarz Stowarzyszenia Psychologii Pastoralnej. Kontakt: awiera@amu.edu.pl

Hubert Pilarczyk - magister teologii, doktorant na Wydziale Teologicznym Uniwersytetu im. Adama Mickiewicza w Poznaniu. Prowadzi badania z zakresu katolickiej nauki o małżeństwie i rodzinie oraz katolickiej nauki społecznej. Kontakt: hubertpilarczyk@wp.pl

Martyna Pilarczyk - studentka IV roku prawa na Wydziale Prawa i Administracji Uniwersytetu Mikołaja Kopernika w Toruniu. Członkini Studenckiego Koła Naukowego Kryminalistyki UMK. W wolnym czasie rozwija swoje zainteresowania artystyczne. Kontakt:268448@stud.umk.pl 